INSIGHTS INTO REGIONAL DEVELOPMENT

ISSN 2669-0195 (online) http://jssidoi.org/IRD/

2020 Volume 2 Number 2 (June)

http://doi.org/10.9770/IRD.2020.2.2(5)

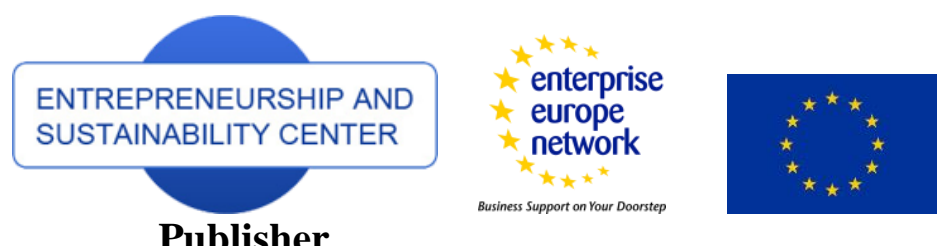

http://jssidoi.org/esc/home

\title{
HUMAN RESOURCE MANAGEMENT EFFECTS ON SUSTAINABILITY OF HIGH-TECH COMPANIES: WHAT LITHUANIA AND SOUTH KOREA CAN LEARN FROM EACH OTHER*
}

\author{
Mindaugas Laužikas ${ }^{1}$, Aistė Miliūtė ${ }^{2}$ \\ ${ }^{1}$ Vilnius University Business School, Sauletekio Av. 22, LT-10225 Vilnius, Lithuania \\ ${ }^{1}$ Global Innovation Learning Ecosystem (GILE) Experts, Corradino Industrial Estate, Paola, Malta \\ ${ }^{2}$ Vilnius University Business School, Saulètekio Av. 22, LT-10225 Vilnius, Lithuania JSC AKVAVITA, Neravu st. 100,
} Viečiūnai, Lithuania

E-mails:를indaugas.lauzikas@gmail.com; 2aiste_miliute@yahoo.com

Received 20 February 2020; accepted 25 March 2020, published 30 June 2020

\begin{abstract}
The literature on the role of intellectual capital on the development of an economy, industry or business is well established (Carnevale and Smith 2013, Lauzikas and Miliute 2017, Kavurmaci 2018, Koehorst et al. 2019, Schoff and Ito, 2019, Koehorst et al. 2019, and etc.). However, the scarcity of holistic transdisciplinary studies regarding factors/ conditions that are critical to unleash the potential of human resources, such as HR Management innovation (Gonera and Pabst 2019, Lee et al. 2019, and etc.), innovation culture (Isaacs et al. 2019, Halim et al. 2019, Sull et al. 2019, Lauzikas and Mokseckiené 2013, Lauzikas and Miliute 2019a, and etc.), creative leadership (Abdi et al. 2018, Jin et al. 2019, Collett et al. 2019, and etc.), modern technologies (Deloitte 2019, Lee et al., Kim et al. 2019, and etc.), new collaboration forms (Kane et al. 2019, Isaacs and Ancona, 2019, Lauzikas and Miliute 2019b, and etc.), social value-added (Wikhamn 2019, Marwede and Herstatt 2019, and etc.) calls for the untapped research potential in the area of Human Resource Management innovation, based on the development stage and peculiarities of cultural and social norms of an economy. The purpose of the present publication is to identify the key drivers of human capital-driven high-tech industries and understand how the Human Resource Management department could help strengthen competitive advantages of high-tech companies in South Korea and Lithuania. The research question is what Human Resource Management innovations are necessary to realign the innovation culture with a specific
\end{abstract}

\footnotetext{
* This research was partly supported by the project,which has received funding from the European Union's Horizon 2020 research and innovation programme European Research Council (ERC) under the European Union's Horizon 2020 research and innovation programme Marie Sklodowska-Curie Research and Innovation Staff Exchanges ES H2020-MSCA-RISE-2014 CLUSDEVMED (2015-2019) Grant Agreement Number 645730730
}
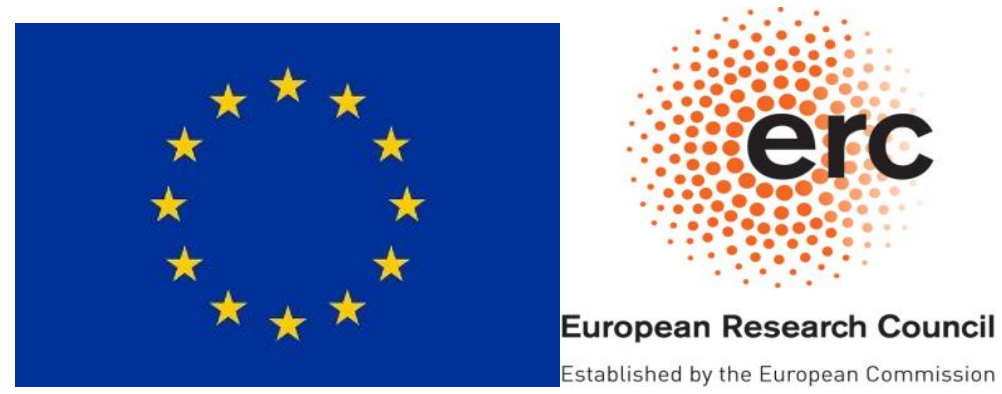
cultural/ social context and a corresponding economic/ business development stage in order to improve companies' competitive position in light of digital transformation of the market. The qualitative semi structured expert interviews led to assumptions and results which explain how human capital links the culture and innovation and why the percentage of commercialized creative ideas in South Korean companies is higher than in Lithuanian companies. In spite of practical and value adding implications and recommendations to both top management and experts of Governmental policies and programs, a more extensive quantitative research should be provided in the next articles of the same series to feel better the global market trends and understand demographic characteristics that affect the organizational behaviour patterns and HRM decisions.

Keywords: human capital; technologies; HRM; innovation; high-tech; leadership; strategy; sustainability

Reference to this paper should be made as follows: Laužikas, M., Miliūtè, A. 2020. Human resource management effects on sustainability of high-tech companies: what Lithuania and South Korea can learn from each other. Insights into Regional Development, $2(2), 562-579$. https://doi.org/10.9770/IRD.2020.2.2(5)

JEL Classification: M130

\section{Introduction}

Although it is impossible to imagine the research on Human Resource Management effects on business sustainability without an adequate attention towards HR innovations, in particular with regards to HR strategies, according to Armstrong and Brown (2019), the topic of HRM impacts on sustainable companies' performance has not been dealt with in depth in order to deliver practical and value-adding implications to both research and business. It is in line with Delery and Roumpi (2017) who call this untapped research potential as 'black box' between HRM techniques and competitive advantages of a company; which might lack a more holistic quantifiable and tangible multi-stakeholder perspective in the literature.

The synergy effect among stakeholders, particularly among various-hierarchy level employees, are emphasized by many scholars. For instance, Isaacs and Ancona (2019) refer to collective intelligence which could be facilitated by effective and efficient strategic communication tools that could engage employees and stakeholders and facilitate innovation commercialization process starting from invention or concept development and finishing with entering a niche or shifting to the mainstream market. Formal innovation implementation process with an appointed individual or cross-departmental committee are necessary to track the progress.

Moreover, successful innovation commercialization process should be based on the previous experience and contain a set of rules that are clear at every organizational unit, for each employee and stakeholder along with intellectual property protection tactics and creative leaders appointed. In parallel with innovation commercialization model, a well-established creativity and innovation enhancement system is necessary to gather community, collect ideas, share resources and expertise. Such complex tasks are nowadays feasible thanks to modern technologies, advanced big data and business intelligence tools as well as continuous collaboration initiatives (Isaacs and Ancona, 2019).

According to Clercq and Pereira (2019), individual employees' commitment could be also expressed and enhanced via personal resources and efforts for innovation, particularly in light of rigid routine work and stressful work life conditions. Hammond et al. (2019) also tackle negative effects of innovation behaviour, particularly in stressful situations, such as shrinking revenue and/ or losing competitive edge: at this stage their innovative mind-sets and efforts might not reach their expectations if business or 


\section{INSIGHTS INTO REGIONAL DEVELOPMENT}

ISSN 2669-0195 (online) http://jssidoi.org/jesi/

2020 Volume 2 Number 2 (June)

http://doi.org/10.9770/IRD.2020.2.2(5)

management processes lack flexibility, proactiveness, and continuous creativity enhancement, while a more strategic and holistic approach towards a challenge is not adopted.

Knowledge and lifelong learning are mentioned as key drivers of effective and efficient management of high-tech companies in the most of literature sources; for instance, according to Tinmaz and Hwa Lee (2019), a sufficient supply and quality of university graduates in terms of their skills and knowledge in 4.0 technologies and processes (Internet of Things (IoT), Artificial Intelligence, Machine Learning, and etc.) might jeopardize development of innovation-driven economies.

The authors emphasize that students might not be ready to perform under extreme market volatility, which requires fast learning, improvisation, big data management and sharp business intelligence competence, along with right attitude and perception towards modern technologies and human resource innovation. Chivot (2019) invites to join the Centre for Data Innovation to discuss the EU's potential of applying AI across various industries: it would be impossible to leverage the value-added of the modern technology without sufficient resources, adequate supply of the talented labour power as well as new policies and/ or programs to support this process.

Unleashing potential of human capital is also accentuated in catching-up economies, such as Nigeria. Having 430 middle managers of four mobile telecommunication companies in Nigeria interrogated, Oladimeji Jamiu Odetunde (2019) introduces a 3-phase innovation model (which includes creativity, innovation and innovation adoption) in order to examine the employees' role in innovation commercialization process. The author came to conclusion that employee creativity directly impacts employee innovation and employee innovation adoption.

While relying on West (2002), Oladimeji Jamiu Odetunde (2019) interprets innovation adoption from both individual and organizational contexts, where employee creativity refers to individual angle while innovation is related to cultural-social context of a company. Although an innovative idea might come from outside of an organization and, thanks to information dissemination and learning process could be adapted (particularly when stakeholders are integrated in innovation commercialization process), the role of employees while generating and commercializing new ideas inside of an organization or efficiently and creatively implementing ideas generated outside a unit should not be diminished. Decision makers should try to adapt optimal innovation culture, which corresponds to cultural-social specificity of a company, because its context affects both individual/ team and organization creativity and innovativeness.

The experts of the Culture is Digital June 2019 Progress Report, prepared by the Department for Digital, Culture, Media and Sport of the UK, go one step deeper and relates innovation culture to big data management (in particular, to data collection and analysis); secondly, describe the situation of digital culture and digital skills and only then overview the progress in innovation processes (including a set of factors, such as the R\&D culture and performance, Innovation and Audience Labs, Immersive Fellowships, Production and Technology). Such a holistic innovation ecosystem is backed by relevance of modern technologies. For example, based on this report, AI could inject additional USD 814 billion to the UK economy by 2035, increasing the annual Gross Value-Added from 2.5 to $3.9 \%$ via larger content of high-tech in more traditional sectors, such as cultural and creative industries (Department for Digital, Culture, Media and Sport, the UK, 2019). Drawing attention to digital culture calls for new innovative 
INSIGHTS INTO REGIONAL DEVELOPMENT

ISSN 2669-0195 (online) http://jssidoi.org/jesi/

2020 Volume 2 Number 2 (June)

http://doi.org/10.9770/IRD.2020.2.2(5)

techniques within the HR Departments, along with enhancement of creativity and competences that are adapted to digital environments.

\section{Supply of Human Capital and Modern Technology: Regional Gaps and Competitiveness}

The modern technology opens new digitalization opportunities across all industries. For example, a team of experts (Leichteris, Izgoroding, Jakubavičius and others), prepared the Lithuanian Industry Digitisation Roadmap 2019-2030 as part of a project of Ministry of the Economy and Innovation. According to the contributors, although the Lithuanian industry is driven by relatively small, smart and agile factories, its value chains are rather international and backed with a rich supply of talented professionals, high-tech solutions and international strategic partnerships. Continuous digitalization and internationalization of business activities via digital hubs, digital innovations, digital competences as well as corresponding commercial digital infrastructure could help Lithuania strengthen its competitive advantages in the region.

The Deloite Insights' Report (2019) draws attention to digitalization as a driving force of innovation in European companies. In spite of a strong focus on the dynamics of patents, Deloite experts recommend to not diminish the role of business models, design, data, organisational innovation and software. Improving competitive advantages in terms of holistic digital technology and innovation, a sustainable and efficient learning system (which corresponds current trends) should be implemented in cooperation with universities. A special attention should be drawn to innovative attitude and culture as well as collaboration among stakeholders via ecosystem of innovation. According to Lee et al. (2019), the strategic direction of innovative business is centred on AI technology, in particular on business model innovation, which can be backed by enhanced AI skills and sustainable learning process.

Internationalisation is a positively contributing factor for high-tech companies from small economies. For instance, based on the 2019 study, prepared by the Lithuanian Laser association, Lithuanian companies continue occupying the largest global market share in scientific lasers sub-industry (1\% of the world's laser revenues of $€ 13.8$ billion in 2018) and showing industry growth of 5.3\% (superior than the global laser market improvement) thanks to international high value-added value chains along with intellectual potential (10\% of employees hold $\mathrm{PhD})$.

According to Carnegie Endowment for International Peace (2019), Along with emergence of modern technologies, such as artificial intelligence (AI), big data, fifth-generation telecommunications networking $(5 \mathrm{G})$, nanotechnology and biotechnology, robotics, the Internet of Things (IoT), quantum computing, and etc., China emerges as one of new leaders of high-tech innovators, particularly in the areas of manufacturing, digital platforms, apps and other social innovation-related technologies, as well as R\&D in the fields of computing and biotechnology. While relying on "Made in China 2025" strategy (New Generation Artificial Intelligence Development Plan), China's performance in intensifying HighLow-tech combination is driven by the purpose to help Beijing possess $70 \%$ presence in high-tech manufacturing by 2025, along with the lead of the most-cited 1\% of published AI papers by 2025 (currently, China is the world leader in patent applications - 40\% global share) (Carnegie Endowment for International Peace, 2019). 
According to Word Preview Outlook for 2024, prepared by EvaluatePharma (2019), the performance of biotechnological companies is driven by innovation, when success of approved products indicates the effectiveness of previous strategic decisions that influence the current or future decision-making process, in particular related to the $\mathrm{R} \& \mathrm{D}$ expenditure (nowadays it is driven by machine learning techniques for the discovery and development of new drugs).

Notwithstanding the growing importance of aspects, such as high-tech research, big data and technological intensity, strong environmental, social and demographic pressures might endanger the profitability of high-tech companies due to stronger R\&D efforts: it is expected that the increase of annual R\&D expenditure from 2018 to 2024 will read $3.0 \%$, while its proportion out of prescription revenue will experience a decrease from $21.6 \%$ to $18.0 \%$. This report provides the examples of top R\&D projects (such as VX-659/VX-445 + Tezacaftor + Ivacaftor, Upadacitinib, DS-8201) and indicate changes in R\&D leaders in terms of expenditure (it is expected that Johnson \& Johnson will overtake Roche in 2024).

Although the Word Preview Outlook for 2024 is focused more on effectiveness and efficiency of R\&D, decision-making process in terms of $R \& D$ priorities and potential success factors call for a wellestablished innovation culture, along with creativity system, big data management, business intelligence and lifelong learning, which are they key focus areas of innovative HR departments.

While evaluating South Korea's potential in the R\&D performance, Kavurmaci (2018) mostly focuses on the supply of educated and skilled human resources, facilitated by national science and technology policies, which affects research efficiency (numbers of patents and articles, ROI from Innovation, technological intensity and economic vs social value-added). Hence, a well-established innovation culture is critical in a country-driven by intellectual capital (such as South Korea and Lithuania), while HRM innovations should liaise culture with strategy as well as support sales, research and international collaboration.

\section{Sustainability via Innovative Human Capital Techniques}

The dimensions of sustainability and social innovation are continuously gaining momentum across various industries, while interpreting these aspects from the perspective of human resource management or learning process. To better understand the specificity of social value-added, it is worth examining industries that are driven by social innovation, such as Healthcare. Based on NHS review (on behalf of the Secretary of State for Health and Social Care, 2019), intellectual capital, in this case Health and Social care employees, should be better prepared for the digital era. For instance, progress of genomics and digital technologies should encourage employees to perfect their competences in illness prevention, to develop and enhance knowledge of advanced treatments and be ready to offer a patient contextsensitive and holistic care, accompanies by advanced management skills. The report is also centred on more interactive collaboration among various stakeholders, including patient-NHS relationship, engaged community and reshaped attitude of stakeholders via creative leadership and innovation culture. Moreover, digitalization requires from employees adding more trans-disciplinary approach to their profession. 
Sustainability and social innovation aspects are also accentuated across various service industries. While examining innovation-customer satisfaction liaison in Swedish hotels, Wikhamn (2019) outlines the role of sustainability of human resource management (HRM) practices. The research reveals the implication, that HR techniques via innovative culture (along with creativity system) make employees and customers more satisfied. Opportunities to enhance employees' skills improve their life quality as well as engage customers through CSR principles; they also improve the social image and popularity of service providers. Based on the literature review of 47 sources, Koster (2019) identifies 3 core axes of innovation in HRM: first of all, it refers to technological process and managerial HR innovation; secondly, innovation impacts on HR are monitored; and finally, it refers to organizational innovation processes. Although the most of the overviewed papers are oriented towards Research and Development, the learning and training also drew a lot of attention in the context of innovative HRM. While linking innovation and culture dimensions, Whee Lee et al. (2019) focus on the effects of HRM on proactivity and group innovation, based on the survey of Korean companies. The authors admit that the social and cultural context affects the HR efficiency in the context of innovation and proactivity, because in general some nations are driven by a particular cultural characteristic (for instance Korean culture is centred on conformity rather than proactivity). Although Whee Lee et al. (2019) did not differentiate between the impacts of HRM effects on psychological states or proactive behaviours of employees, the study led to implications that it is possible to affect proactiveness via employees' competence, motivation and perception of management, while proactive behaviour may orient employees to organizational goals. Moreover, innovation success could positively contribute to a better social image of a company and employees' satisfaction, while proactive employees lead to higher team creativity and efficiency.

While analysing 495 empirical studies on 516 HR systems, Boon, Hartog and Lepak (2019) try to measure the role of holistic HR systems rather than focusing fragmented practices, particularly from different time and development stage perspectives (it appears that some practices are more important than others). In the longer run, the interrelations between various dimensions of a HR system and its value-added can become more pertinent and clearer; hence, tracking and continuously researching this area could be a worthy pursuit. Both more generic interpretation of Strategic Human Resource Management and specific topics of this field are of significant interest; while efficiency at various organizational levels (Peccei \& Van De Voorde, 2019) is interpreted from both a social and economic perspective.

Within 2019 Information Services Group report on challenges and opportunities HR-driven organizations face nowadays (with 271 companies from key geographic regions), the organizational capability to use HR technologies emerges as a vital precondition for sustainability. The capability levels are classified into stages which correspond company's lifecycle, strategy, readiness and its competitive position. For instance, to reach the 4th level of ISG HR Tech Capability Model, the HR department should not only fit strategic directions of a company, but also provide a sufficient access to modern technologies and possess a system to upgrade organizational technological skills. Moreover, this system should be run by integrated business intelligence hub, big data management and strong leadership. According to Information Services Group (2019), in order to become a digital and global player (via improving employee comfort, optimizing OPEX, enhancing innovation and employee engagement) the use and role of HR technologies should be concrete and clear at each strategic development stage; should be continuously monitored by supporting this process with big data, as well 
INSIGHTS INTO REGIONAL DEVELOPMENT

ISSN 2669-0195 (online) http://jssidoi.org/jesi/

2020 Volume 2 Number 2 (June)

http://doi.org/10.9770/IRD.2020.2.2(5)

as become a natural part of culture, which is open and flexible to technological changes (particularly AI and robots) and social vulnerabilities.

\section{Methodology}

Based on Digital Competitiveness Ranking (2019), innovation culture is anchored in 3 foundations: knowledge, technology and future readiness. South Korea is ranked 10th while Lithuania is ranked 30th out of 63 countries. Lithuania and South Korea, in spite of social-cultural differences, economic regional context and size, are both driven by Intellectual capital and high-tech development; thus, these economies could learn a lot from each other. For example, Lithuania occupies the No. 1 spot in terms of digital and technological skills and possesses rather high positions in numbers of female researchers, higher education achievement, enforcing contracts, Communication Technology, agility of companies, use of big data and analytics, cyber security, as well as equilibrium between new opportunities and threats (6st, 11th , 7th, 4th, 4th, 11th, 15th and $7^{\text {th }}$, respectively), but this Baltic state needs to strengthen its positions in terms of net flow of international students (54th), R\&D productivity by publication (55th), Immigration Laws (53rd) and smartphone possession (56st).

In the meantime, South Korea is ranked No.1 in terms of R\&D spending, E-Participation and Internet retailing; occupies the 3rd place in terms of higher education achievement, High-tech patent grants, IT \& media stock market capitalization, E-Government, world robots distribution; and being positioned the second out of 63 countries in terms of Internet bandwidth speed and enforcing contracts. However, this Asian leader should strengthen its position in terms of female researchers, net flow of international students, International experience, Immigration Laws, banking and financial services (53rd, 50th, 52th, 61 st, 54th respectively).

Taking into consideration that both countries have strong positions in IT industry, thanks to relatively high numbers of graduates and proportionally high share of foreign direct investments in this sector, experts' insights and experiences regarding development and usage of digital platforms (selling goods or services) also helps explain the evolution of HR culture in these economies.

In order to leverage the human capital potential and increase the effectiveness and efficiency of the HR Departments' performance via innovation culture (which should affect various competitive advantages of a high-tech company) the experts where asked to fill the matrix of metamorphosis of innovative HRM, while indicating its impacts on various strategic goals. It is obvious, that responses to these questions are rather perception-driven and might be related to the specificity of a company (its size, lifetime, competitive position, and etc.); however, they incorporate the key economy and entrepreneurship development trends, along with cultural and social norms, of the two compared countries. On the other hand, the majority of similar qualitative expert interviews are perception and experience-based, which make the matrix of significant interest.

To better answer the research question what Human Resource Management innovations could help realign the innovation culture with a specific cultural/ social context and a corresponding economic/ business development stage in order to improve companies' competitive position, the in-depth qualitative interviews with top managers (with over 7-year management experience in high-tech) of 6 
Lithuanian and 6 South Korean IT companies were conducted; the responses of the Lithuanian and South Korean experts were compared and suggestions how to unleash human capital potential via innovative human resource techniques were provided for corporate professionals and policy makers.

\section{Research on Human Resource Strategies within Lithuanian and Korean IT companies}

An interesting discovery of the present research is related to the areas to which the creative ideas of South Korean and Lithuanian entrepreneurs are oriented. These areas are also liaised with the main strategic targets of high-tech companies, where culture and innovation could work in harmony to reach business sustainability which can be translated by economic/ social situation of the compared economies. As it could be expected, the entrepreneurs from economically more advanced South Korea, centred their activities on productivity (stated by 4 out of 6 experts). Moreover, all the experts underlined that a sufficient human resource supply must be provided as a key business driver in order to strengthen the competitive advantages of a company.

While acknowledging the significance of human capital on business performance, the interviews outlined that the maturity and social responsibility of companies could be reached (given a sufficient supply of human resources) if culture and innovation properly motivate teams and individuals. Notwithstanding that the role of intellectual capital was mentioned in Lithuanian companies, the Lithuanian entrepreneurs emphasized more the dimensions of Corporate Social Responsibility, creativity enhancement system and social innovation rather than focusing on HR efficiency. It might be related to somewhat bigger socially vulnerable groups in the economy along with the growing demand for hightech specialists due to rapidly increasing Foreign Direct Investment in high-tech industries, as well as a somewhat more remarkable specialization of Nordic Europe in activities inclined to positive externalities (environmental protection, healthy living, natural/ organic production, and etc.).

Answering the question what new opportunities can modern technologies open up for nascent (starting) businesses, the interviewed entrepreneurs relate the technology effects to the main strategic goals or business efficiency criteria of a company. For instance, the Korean experts emphasized technological impacts while improving and managing productivity by combining big data with AI or finding a new niche to provide a service while developing and maintaining programs for AI capabilities. The Lithuanian experts accentuated HR technologies, AI and Business Intelligence solutions, in parallel with technological solutions to increase social trust, mitigate effects of fear of failure and enhance collaboration activities. Such results show that the interrogated experts feel well the development specificity of their industries and can easily indicate the existing gaps in practices and strategies enhancing the talent development and management.

Based on the Lithuanian high-tech experts, the liaisons between culture and innovation are more related to the HR department (creativity enhancement, talent development, team management, application of modern communication technologies). Such trends correspond to the main development priorities of each economy and industry and shows that high tech experts acknowledge the context of their market and organization and orient the HRM to the development stage of their companies.

The difference in HR strategies between Korean and Lithuanian high-tech firms is remarkable: in the case of South Korea it is related to the R\&D culture, while in the case of Lithuania, HR techniques are a 
key axis of sustainable and innovative business. The difference could be illustrated by the process how to decide which idea to implement. Korean experts represent companies which already have well established innovation climate: rather than focusing on creativity system development, they focus more on how this creativity system support R\&D efficiency and value-added. Profit margins and core efficiency were mentioned by Korean respondents in terms of quantitative KPI-s, while the Baltic experts used more qualitative criteria.

Given a strong organizational structure to support innovation processes in innovation leaders' economies (within interrogated Korean companies there are minimum 2-3 departments and 5-6 people involved in innovative ideas commercialization), the key priority is to use this innovation process and culture while generating the economic and social value-added. As it could be expected the Lithuanian experts had CEO, Marketing or sometimes HR department in charge of creativity or new concepts; however, these innovation processes were rather fragmented without a well-established cross-departmental structure to manage innovation commercialization process.

Intellectual capital is of significant importance for innovation commercialization; however, a sufficient financial input and the quality of the R\&D department are also critical, although it is definitely related to the development stage of a company, industry and/ or economy. Two Korean experts argue that it is important to invest not less than $10 \%$ out of revenue in $R \& D$, while the other four indicate the values from 20 to $35 \%$ or over, compared to up to $10-20 \%$ of R\&D expenditure, indicated by the Lithuanian experts. This might be related to the assumption that not every high-tech expert understands the complexity of R\&D due to lack of knowledge or insufficient business intelligence skills or simply the innovation culture is under the process of development at the present moment and it might take a few years to have the R\&D process well-established, effective and efficient. Thus, the role of the HR departments will be crucial to overcome these weaknesses.

Both the Lithuanian and Korean experts agree that a successful company should invest in R\&D a relatively high percentage of revenue in order to be edgy and innovative; However, the South Korean experts emphasize more the quality and efficiency of R\&D performance and apply more quantitative indicators to measure success of innovation performance. It is interesting to note that the Korean experts demonstrate their knowledge in combining innovation strategy with other strategies (including the business strategy of a company). In order to commercialize innovative ideas, decision makers should understand the specificity of their target market, competitors' skills level, development capability and cost of a company, as well a future strategic outlook: all these elements can be reached only via modern technologies with strong HRM competences and monitoring (which indicate companies' long-term orientation and sustainability).

The Lithuanian experts emphasize a great number of dimensions related to social value-added, such as CSR and shared value economy; however, a clear and strong HR department which could be responsible for measuring and monitoring success of these processes is vacant along with technologies providing shareholders accountability reports or engaging customers in decision-making. This is related to transformation of Lithuanian high-tech industry towards a holistic, sustainable, long-term oriented, accountable and consistent system, where companies tend to learn from their mistakes, while innovation commercialization success is tracked and documented online. 
In parallel with a strong $R \& D$ performance, accompanied by well-implemented innovation and monitoring functions as well as organizational orientation towards long-term strategic targets, the Korean high-tech specialists admitted that their creativity enhancement system could be graded as 9 out of 9 (stated by experts): their performance is highly encouraged via sustainable learning and creative processes because the enhancement of their skills and creativity are vital to survival and expansion of a company. The Lithuanian experts were more pessimistic regarding creativity encouragement models (the average value of 6), which illustrates the areas of improvement for the HR department.

Notwithstanding a better-developed creativity system in the Korean environment, Lithuanian and Korean high-tech experts were equally involved in innovative projects (twice a year or more frequently). Such result could be related to Lithuania's high rates in terms of intrapreneurship and the efficiency of Korean high-tech creativity systems. It could be also noted that the Korean experts perceive intrapreneurial activities as a logical and formal part of a creativity system, while in the case of Lithuanian IT firms it is more formalized and not integrated into innovation culture of a company.

The Korean experts were not afraid to acknowledge and use their previous employment experience in the development of their own business, since it was related to their current career - they felt more confident to admit that their new career was a spin-off from previous employments. The Lithuanian experts were more intimidated to speak about their intrapreneurship experience, which makes believe that the organizational culture among Lithuanian companies does not fully support these processes; intrapreneurship initiatives are not encouraged and formalized. This implication is related to a set of cultural norms, including social capital dimensions (such as fear of failure, social risk, uncertainty avoidance, risk management, long/ short-term orientation, power distance, transparency, and many others). For instance, if employees are not confident about their future and are afraid to fail, they will prefer to leave the risk management function to their employer. When the self-esteem and creativity encouragement system is not present, entrepreneurs do not shift towards independent entrepreneurship or partial entrepreneurship with 'Win-Win' strategy developed together with a current employer.

When social trust is broken, high-tech experts might feel uncomfortable to use digital hubs involving other stakeholders, in particular, because they do not tolerate their mistakes or failures; it also indicates that monitoring and risk management processes could be fragmented or weakly developed. Thus, innovation culture, which is one of the prerogatives of the HR department, is the most important precondition for intrapreneurship, while vacant intrapreneurship encouragement processes could cause frustration, stress and anxiety among employees and other stakeholders. Such results also explain the reason why the Lithuanian high-tech experts are focusing more on the HR department while linking innovation with culture, contrary to the Koreans who use it as a natural tool to improve efficiency and competitive position in the market.

Representatives of both countries indicated similar technology effects on the development of entrepreneurship activities: first of all, it affected the market share and brand via digitalization, secondly it enabled bigger economic and social value-added via shared value economy or social impacts (such as environmental protection by saving $\mathrm{CO} 2$ production or access to education). In the longer run, the entrepreneurship dynamics could show success of linking innovation and culture via technologies, while focusing on a set of factors (\% of established businesses, commercialization success of innovation in 


\section{INSIGHTS INTO REGIONAL DEVELOPMENT}

ISSN 2669-0195 (online) http://jssidoi.org/jesi/

2020 Volume 2 Number 2 (June)

http://doi.org/10.9770/IRD.2020.2.2(5)

terms of revenue from new products or patents, \% of commercialized new ideas, growth of revenue and profit, and other competitive advantages).

In terms of main key-words that are related to social contributions, the interrogated experts accentuated the following ones: social impact, shared value economy, social entrepreneurship, environmental protection, healthcare, social innovation, Corporate Social Responsibility, digitalization, robots, and etc., which shows that the high-tech experts are sufficiently knowledgeable in terms of what social value a modern technology could create via innovation of the HR Department.

The Korean tackled new challenges that nowadays technologies could create while shifting employees from a pure executor to intermediary between technologies and people (for instance, AI replaced technical services that were manually developed by skilled workers and led to reduction in the demand for skilled personnel and the provision of high quality technical services), while the Lithuanian experts focused on the development of creativity system which would help employees find their natural talent zone and niche in the future as well as contribute to success of their entrepreneurial ventures.

The Korean experts' experience in digital platforms is further illustrated by their concrete technical examples of technology effects (for instance, building energy management or factory energy management service via AI and big data management techniques or improving renewable energy sub industry via digital platforms). The Lithuanian experts emphasized the increasing importance of digital platforms on business success, but their knowledge and perception were more generic and fragmented. Although both the Lithuanian and Korean experts agreed that they needed to implement or upgrade new technologies at least once per 2 years, the sustainability and accountability towards various stakeholders (including employees, partners and customers) via digital platforms was more accentuated by the Asian respondents: their sustainability description was more specific (for instance, AI-applied technology must be developed through industry-academia or in-house development), monitoring was well established and effective, while culture supported the technological development. Such equilibrium between innovation and culture helped leverage technologies and make business more sustainable (for instance, building energy management technology using AI and big data helped business survive by increasing price competitiveness).

Given a somewhat richer and longer HR experience while developing and enhancing innovation culture in South Korea (where innovation process is well-established, creativity is encouraged and rewarded, the system of innovation is driven by smooth communication via digital hubs, and etc.) it is not surprising that the Korean experts ( 5 out of 6 ), more than Lithuanian experts ( 2 out of 6 ), indicated communication during the time of change, society engagement, creativity system, and even meeting stakeholders' expectations as competitive advantages which were created thanks to their experience of liaising innovation and culture via the HR Department.

The experts admitted that their efforts to conduct HR innovations helped gather and engage society, create sustainability-centred philosophy and values as well as match employees', customers' and strategic partners' expectations. All these impacts were less emphasized by the Lithuanian experts due to challenges related to fear of failure, uncertainty avoidance, power distance or social trust, as well as a relatively modest experience of implementing a creativity ecosystem with a proper well-developed organizational structure to run continuous and effective innovation processes. Moreover, the South 
Korea's advantage in terms of R\&D transfer also contributed to experts' emphasis on their strong competitive position while developing and sharing knowledge and using untapped potential of educational organizations.

The experts of both countries admitted that their attempts to link the HR culture with growth (breakeven, switching to mainstream) are not always successful, as the whole market (including other peers) face the same threats and pressures (for instance contributions to healthier living, environmental protection, safety and security), which require a higher-level flexibility, monitoring, creativity and efficiency. The economy plays an important role on pricing, quality and profit margins (due to demand factors and business development trends) within high-tech industries of each economy; however, based on research results, the affordability and access to innovative products was a stronger competitive advantage of Lithuanian high-tech companies. Moreover, the similarity of the analysed economies' high-tech industries is also witnessed in terms of social value-added generation and harmony with nature, which shows the maturity and sustainability of both economies (See Image 1).

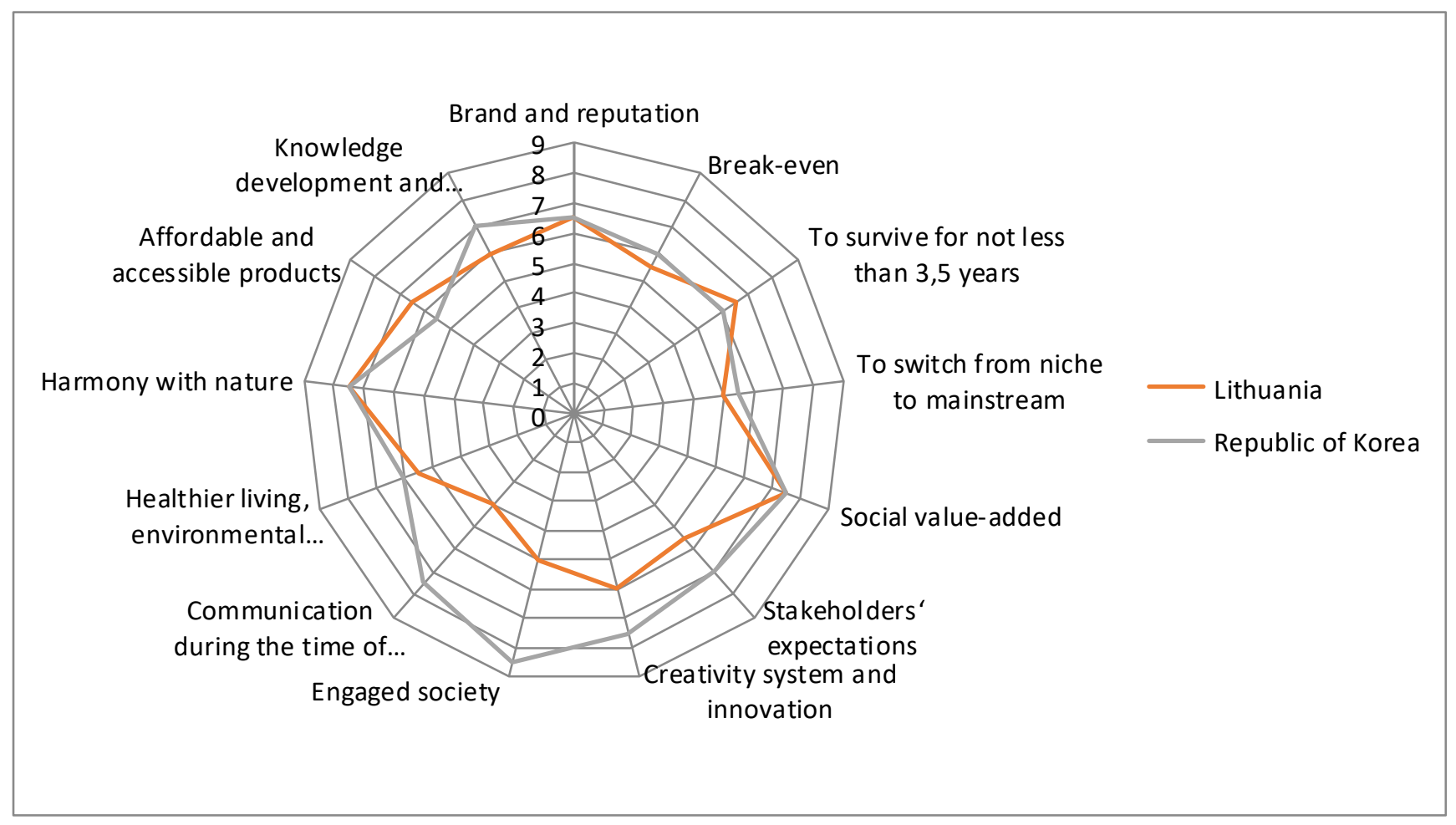

Image 1. Human Resource Management Effects on Sustainability of High-Tech Companies: how important is innovation culture while strengthening competitive advantages of high-tech companies (in the scale of 9 ; where 9 refers to particularly important, 1 - not important) Source: Prepared by paper authors, based on experts' responses

In spite of similarity of the analysed economies, the IT companies in these two markets are at different evolution stages. Having a richer and longer experience in building innovation culture via HR, South 
Korea is more focusing on the R\&D efficiency, although the HR function should be continuously up-todated via process innovation and modern technology in order to maintain the leading position. The Lithuanian experts emphasized the context of rapid development of this economy, where in order to respond to the market changes and consumer expectations, high-tech companies need to skip some steps of innovation culture development without having time to realign cultural aspects towards global pressures; thus, it would be suggested to focus more on innovative HR techniques, a holistic culture and sustainability (See Image 2).

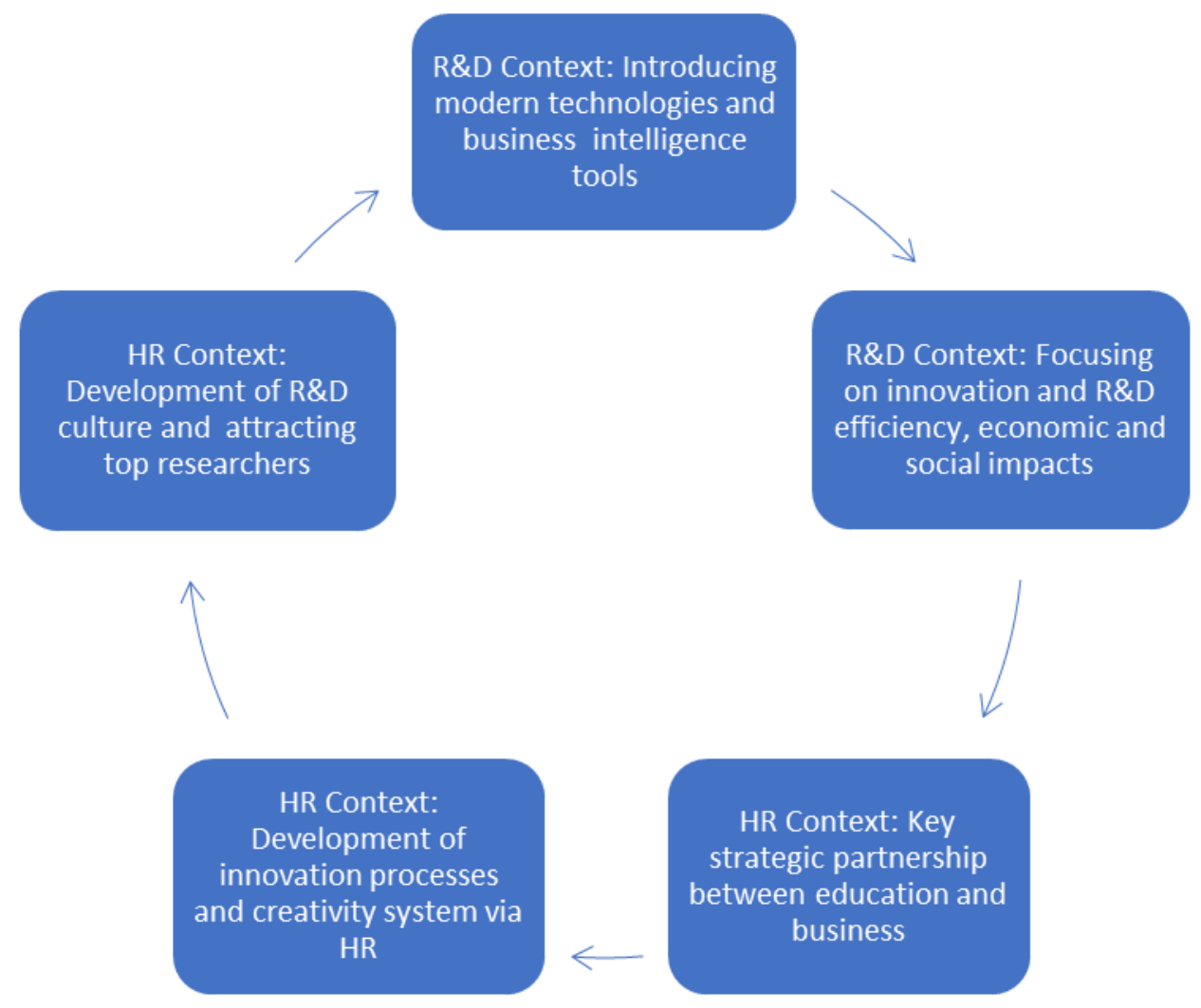

Image 2. The Role of HRM and R\&D dimensions within the Evolution of Competitive Advantages of IT Firms Source: Prepared by paper authors, based on experts' responses

\section{Conclusions and Recommendations}

Given the increasing role of innovation culture, HR departments' function in building self-esteem, creativity enhancement, creative leadership, intrapreneurship and many other aspects are critical, along with monitoring, business intelligence and strategic collaboration. Having no understanding why and how technologies are applied, how they work within decision-making model, it is very difficult to identify efficiency criteria of innovative Human Resource Management, which should lead to sustainable business performance, including the technological improvement. The majority of innovation 


\section{INSIGHTS INTO REGIONAL DEVELOPMENT}

ISSN 2669-0195 (online) http://jssidoi.org/jesi/

2020 Volume 2 Number 2 (June)

http://doi.org/10.9770/IRD.2020.2.2(5)

initiatives should come from employees and other stakeholders if culture is friendly and open to new ideas.

The Lithuanian experts focused on leveraging employees' potential and following a positive experience of South Korea, which similarly to Lithuania didn't have abundance of natural resources and used the potential of high-tech specialists in attracting high-tech investors or developing new ventures in their economy. At macro or mesa level, this transformation trend calls for the improvement of High-Tech study programs at Lithuanian universities and strengthening the role of $\mathrm{R} \& \mathrm{D}$ transfer mechanisms in order to supply an adequate number of graduates for high-tech investors. Thus, at micro and mesa levels, the emphasis on the HR department in Lithuania's case is logical and effective.

A well-established innovation culture, which derives from the Human Resource Department, leads to the ratio of commercialized creative ideas in South Korean companies, slightly higher than in Lithuanian companies (two Korean experts indicated the level up to $25 \%$ while the other four underlined the bracket from $25 \%$ to 50\%; within Lithuanian interrogated companies this number did not exceed one fifth of total ideas).

The comparison of responses of high-tech experts from Lithuania and South Korea is useful for both economies: in spite of their geographical location, differences in cultural and social norms, size and development stage of economies and interrogated firms (they are similar in many aspects, such as education levels, specialization in high-techs or limited natural resources). Therefore, Lithuanian experts could apply the Korean experience in developing a stronger innovation culture with new forms of activities and interaction opportunities between technologies and people (as well as emphasizing the role of the R\&D culture), while Korean experts should not take the already developed HR culture for granted and continuously perfect their HR strategies, because the new generations (along with new social pressures) could completely change the rules of the game; thus the innovation system should be open and continuously nourished in order to keep the leading position in the market.

Based on the experts' and scholars' insights, the HR departments in Lithuanian high-tech companies should adopt a holistic bidirectional innovation commercialization model: on the one hand, modern technology and process innovation should help diminish the fragmentation and inefficiency of innovation culture (including creativity system and knowledge transfer) and HRM overall (this process should be rapid and of the first priority), while the R\&D and technological improvement dimension should be continually emphasized and strengthened to improve the competitive position in the market. However, abundant HR innovations should be continuously and straight away applied in the R\&D projects in order to support other departments (such as Sales and Marketing or R\&D). To diminish the gap in HR culture, the accelerated innovation process calls for organic creativity and intrapreneurship ecosystem, faster trial and implementation of technological and managerial innovation as well as more ingenious business intelligence tools while tracking both implementation success of HR techniques and innovation commercialization performance. In spite of complexity of a holistic bidirectional innovation commercialization model, such complex tasks are possible in human capital and education-driven Lithuanian IT companies, if a sustainable and efficient learning process is implemented. 
INSIGHTS INTO REGIONAL DEVELOPMENT

ISSN 2669-0195 (online) http://jssidoi.org/jesi/

2020 Volume 2 Number 2 (June)

http://doi.org/10.9770/IRD.2020.2.2(5)

\section{References}

Abdi, K.; Mardani, A.; Senin, A.A.; Tupentaite, L.; Naimaviciene, J.; Kanapeckiene, L.; Kutut, V. (2018). The Effect of Knowledge Management, Organizational Culture and Organizational Learning on Innovation in Automotive Idustry. Journal of Business Economics and Management, Vol. 19, No. 1, pp. 1-19 https://doi.org/10.3846/jbem.2018.1477

Armstrong, M.; Brown, D. (2019). Strategic Human Resource Management: Back to the future? A literature review, Report 517, p. 50, Available online: https://www.employment-studies.co.uk/system/files/resources/files/517_Strategic-Human-Resource-Management-Backto-the-future-IES-CIPD-2019.pdf

Atkinson, R.D.; Foote, C. (2019). Is China Catching Up to the United States in Innovation? p. 57, http://www2.itif.org/2019-chinacatching-up-innovation.pdf

Boon, C.; Hartog, D.N.D.; Lepak, D.P. (2019). A Systematic Review of Human Resource Management Systems and Their Measurement. Journal of Management, Vol. 45, No. 6, pp. 2498-2537, DOI: https://doi.org/10.1177/0149206318818718

Carnevale, A.P.; Smith, N. (2013). Workplace basics: the skills employees need and employers want. Human Resource Development International, Vol. 16, pp. 491-501, https://doi.org/10.1080/13678868.2013.821267

Centre for Data Innovation by Chivot, E. (2019). Call for European AI Policy Conference, March 25, 2020, available online: https://www.datainnovation.org/2020/03/european-ai-policy-conference/

Clercq, D.; Pereira, R. (2019). Resilient employees are creative employees, when the workplace forces them to be. Creativity and Innovation Management, Vol. 28, No. 3, pp. 329-342, https://doi.org/10.1111/caim.12328

Collett, C.; Graham, J.; Lindsay, J. (2019). Innovative leaders \& leading innovation. A Theoretical and Practical Analysis White Paper. iOpener Institute for People \& Performance, An iOpener Institute Research Paper, May, p. 30, https://iopenerinstitute.com/wpcontent/uploads/2019/05/Innovative-Leaders-and-Leading-Innovation_-May-2019.pdf

Delery, J.E.; Roumpi, D. (2017). Strategic human resource management, human capital and competitive advantage: is the field going in circles? Human Resource Management Journal, Vol. 27, No. 1, pp. 1-21, https://doi.org/10.1111/1748-8583.12137

Deloitte by Kaji, J.; Hurley, B.; Gangopadhyay, N.; Bhat, R.; Khan, A. (2019). Leading the social enterprise: Reinvent with a human focus, 2019 Deloitte Global Human Capital Trends, p. 112, https://www2.deloitte.com/content/dam/insights/us/articles/5136 HC-Trends2019/DI_HC-Trends-2019.pdf

Deloitte, prepared by Seeger, S.; Hurley, B.; Bhat, R. (2019). Innovation in Europe. A Deloitte survey on European companies and how digital technologies can strategically enhance innovation, https://www2.deloitte.com/content/dam/insights/us/articles/DE_897_Innovation-in-Europe/DI_Innovation-In-Europe.pdf

Department for Digital, Culture, Media and Sport, the UK (2019). Culture is Digital, June 2019 Progress Report, p. 38, Available online: www.gov.uk/dcms

EvaluatePharma (2019). World Preview 2019, Outlook to 2024, 12th Edition - June 2019, p. 26, https://info.evaluate.com/rs/607-YGS364/images/EvaluatePharma_World_Preview_2019.pdf

Gonera, A., Pabst, R., (2019). The Use of Design Thinking in Transdisciplinary Research and Innovation Consortia: Challenges, Enablers and Benefits. Journal of Innovation Management, Vol. 7, No. 3, pp.96-122, DOI: https://doi.org/10.24840/2183-0606_007.003_0006

Halim, H.A.; Ahmad, N.H.; Ramayah, T. (2019). Sustaining the Innovation Culture in SMEs: The Importance of Organisational Culture, Organisational Learning and Market Orientation. Asian Journal of Business Research Vol. 9, No. 2, p. 20. https://doi.org/10.14707/ajbr.190059

Hammond, M.; Cross, C.; Farrell, C. Eubanks, D. (2019). Burnout and innovative work behaviours for survivors of downsizing: an investigation of boundary conditions. Creativity and Innovation Management, Vol. 28, No. 3, pp. 306-317. https://doi.org/10.1111/caim.12327

Isaacs, K.; Ancona, D. (2019). 3 Ways to Build a Culture of Collaborative Innovation, Harvard Business Review, August 12, 2019, https://hbr.org/2019/08/3-ways-to-build-a-culture-of-collaborative-innovation 


\section{INSIGHTS INTO REGIONAL DEVELOPMENT}

ISSN 2669-0195 (online) http://jssidoi.org/jesi/

2020 Volume 2 Number 2 (June)

http://doi.org/10.9770/IRD.2020.2.2(5)

ISG Confidential (2019). 2019 Industry Trends in HR Technology and Service Delivery. A report exploring the challenges and opportunities facing HR organizations today, 2019 March, p. 33, https://isg-one.com/docs/default-source/default-document-library/2019hr-tech-survey-report.pdf?sfvrsn=9f64c231_0

Jin, Z.; Navare, J.; Lynch, R. (2019). The relationship between innovation culture and innovation outcomes: exploring the effects of sustainability orientation and firm size. R\&D Management, Vol. 49, No. 4, pp. 607-623, https://doi.org/10.1111/radm.12351

Kane, C.G.; Palmer, D.; Phillips, A.N.; Kiron, D.; Buckley, N. (2019). Accelerating Digital Innovation inside and out; Agile Teams, Ecosystems, and Ethics, MIT Sloan Management Review, June 04, Findings from the 2019 Digital Business Global Executive Study and Research Project In collaboration with Sponsor Logo, https://sloanreview.mit.edu/projects/accelerating-digital-innovation-inside-and-out/

Kavurmaci, A. (2018). The Place of R\&D and Education Policies in South Korea's Economic Development Journal of Social Policy Conferences, Vol. 74, pp. 51-64, https://doi.org/10.26650/jspc.2018.74.0003

Kim, H.; Park, S.Y.; Joh, W.I. (2019). A Study on Technology Development Performance and Technology Commercialization Performance (According to the Technology Development Capability of SMEs Focusing on a Comparative Analysis of Technology Business Groups). Journal of Open Innovation: Technology, Market, and Complexity, Vol. 5(3), No. 65, p. 19, https://doi.org/10.3390/joitmc5030065

Koehorst, M.; van Deursen, A.; van Dijk, J.; De Haan, J. (2019). Exploring the Creative Industries: toward a Classification by Process and Job Functions. Journal of Innovation Management, Vol.7, No.3, pp. 69-95, DOI: https://doi.org/10.24840/2183-0606 007.003 0005

Lauzikas, M.; Mokseckienė, R. (2013). The Role of Culture on Entrepreneurship in Lithuania. Social Research, No. 2, Vol. 31, pp. 55-69, ISSN 1392-3110, https://vb.mruni.eu/object/elaba:6092663/

Lauzikas M.; Miliute A. (2017). The Role of Education on Entrepreneurship in Lithuania. In: Sauka A., Chepurenko A. (eds) Entrepreneurship in Transition Economies. Societies and Political Orders in Transition. Springer, Cham; ISBN: 978-3-319-57341-0 (Print) 978-3-319-57342-7, https://doi.org/10.1007/978-3-319-57342-7_9

Lauzikas, M.; Miliute, A. (2019a). Transformational Communication via Evolving Ethical and Moral Norms of Lithuanian Civil Service Organizations, Entrepreneurship and Sustainability Issues, Vol. 6, No. 4, pp. 1750-1761, https://doi.org/10.9770/jesi.2019.6.4(14)

Lauzikas, M.; Miliute, A. (2019b). Communication Efficiency and Effectiveness within Strategic Management of Change: insights into Civil Service Organizations, Journal of Security and Sustainability Issues, Vol. 8, No. 4, pp. 617-630, https://doi.org/10.9770/jssi.2019.8.4(6)

Lee, H.W.; Pak, J. Kim, S.; Li, L.Z. (2019). Effects of Human Resource Management Systems on Employee Proactivity and Group Innovation. Journal of Management, Vol. 45, No. 2, pp. 819-846, https://doi.org/10.1177/0149206316680029

Lee, J.; Suh, T.; Roy, D.; Baucus, M. (2019). Emerging Technology and Business Model Innovation: The Case of Artificial Intelligence. Journal of Open Innovation: Technology, Market, and Complexity, Vol. 5(3), No. 44, p. 13, https://doi.org/10.3390/joitmc5030044

Leichteris, E.; Izgorodin, A.; Jakubavičius, A.; Jasėnas, A.; Kudarauskienė, A.; Van Der Molen, S.; Leiputė, B.; Bacevičius, P. (2019). Lithuanian Industry Digitisation Roadmap 2019-2030, Ministry of the Economy and Innovation, p. 17, https://industrie40.1t/wpcontent/uploads/2019/03/Lithuanian-Industry-Digitisation-Roadmap-2019-2030_final.pdf

Lithuanian Laser association (2019). Laser Technologies in Lithuania, publication initiated and published by the Fifth revised edition, p. 29, http://www.Itoptics.org/uploads/documents/Laser\%20Technologies\%20in\%20Lithuania_2019.pdf

Marwede, M.; Herstatt, C. (2019). No innovation for the elderly? The influence of cognitive distance in corporate innovation. Creativity and Innovation Management, Vol. 28, No.3, pp. 355-367, https://doi.org/10.1111/caim.12318

NHS, The Topol Review (2019). Preparing the healthcare workforce to deliver the digital future. An independent report on behalf of the Secretary of State for Health and Social Care, p. 53, https://topol.hee.nhs.uk/wp-content/uploads/HEE-Topol-Review-2019.pdf

Odetunde, O.J. (2019). Employee Innovation Process: An Integrative Model. Journal of Innovation Management, Vol. 7, No. 3, pp. 15-40, https://doi.org/10.24840/2183-0606_007.003_0003 
INSIGHTS INTO REGIONAL DEVELOPMENT

ISSN 2669-0195 (online) http://jssidoi.org/jesi/

2020 Volume 2 Number 2 (June)

http://doi.org/10.9770/IRD.2020.2.2(5)

Peccei, R., Van De Voorde, K. (2019). The application of the multilevel paradigm in human resource management - outcomes research: taking stock and going forward. Journal of Management, Vol.45, No. 2, pp. 786-818, https://doi.org/10.1177/0149206316673720

Koster, F. (2019). Innovative HRM. A Review of the Literature. Journal of Technology Management \& Innovation, Vol. 14, No. 2, pp. 97106, ISSN: 0718-2724, Available online: https://scielo.conicyt.cl/pdf/jotmi/v14n2/0718-2724-jotmi-14-02-97.pdf

Schoff, J.L.; Ito, A. (2019). Competing with China on Technology and Innovation, Alliance Policy Coordination Brief, Carnegie Endowment for International Peace, October, p. 17, https://carnegieendowment.org/files/ChinaRiskOpportunity-China_Tech.pdf

Sull, D.; Sull, C.; Chamberlain, A. (2019). Measuring Culture in Leading Companies, MIT Sloan Management Review and Glassdoor, June 2019, p.17, https://www.glassdoor.com/research/app/uploads/sites/2/2019/06/Measuring-Culture-Final.pdf

Tinmaz, H.; Lee, J.H. (2019). A Preliminary Analysis on Korean University Students' Readiness Level for Industry 4.0 Revolution. Participatory Educational Research (PER), Vol. 6, No, 1, pp. 70-83, ISSN: 2148-6123, http://dx.doi.org/10.17275/per.19.6.6.1

West, M.A. (2002). Sparkling fountains or stagnant ponds: An integrative model of creativity and innovation implementation in work groups. Applied Psychology: An International Review, Vol. 51, No. 5, pp. 355-387, https://doi.org/10.1111/1464-0597.00951

Wikhamn, W. (2019). Innovation, sustainable HRM and customer satisfaction. International Journal of Hospitality Management, Vol. 76, pp. 102-110, 0278-4319 https://doi.org/10.1016/j.ijhm.2018.04.009

\section{Acknowledgements}

This research was partly supported by the project, which has received funding from the European Union's Horizon 2020 research and innovation programme European Research Council (ERC) under the European Union's Horizon 2020 research and innovation programme Marie Sklodowska-Curie Research and Innovation Staff Exchanges ES H2020-MSCA-RISE-2014 CLUSDEVMED (2015-2019) Grant Agreement Number 645730730
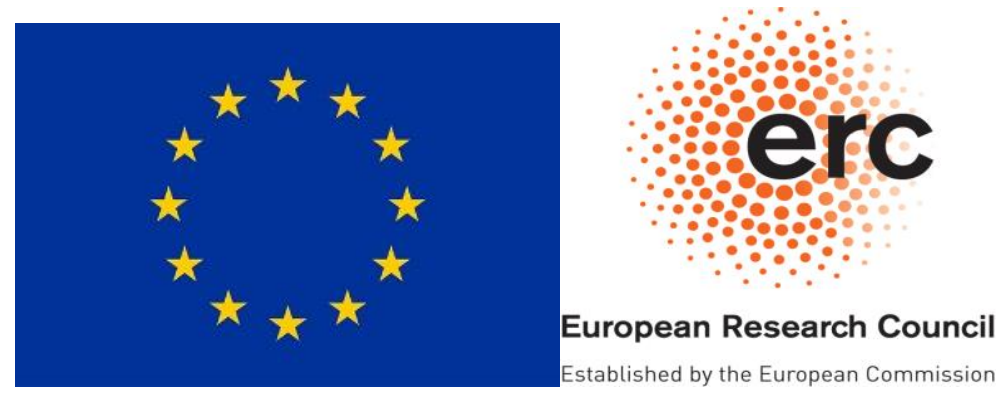
INSIGHTS INTO REGIONAL DEVELOPMENT

ISSN 2669-0195 (online) http://jssidoi.org/jesi/

2020 Volume 2 Number 2 (June)

http://doi.org/10.9770/IRD.2020.2.2(5)

Dr. Mindaugas LAUŽIKAS is a Professor at Vilnius University Business School, Adjunct Professor at American University of Malta, Doctor of Economic Sciences, Director of GILE Experts (Malta). Lecturing experience in countries, such as Georgia, Sweden, France, Spain, Italy, Malta, Moldova, South Korea and Lithuania, is supported by publications in the field of knowledge economy, entrepreneurship and innovation. Research interests: national systems of innovation, entrepreneurship, knowledge and innovation management, innovation and human resource strategies, business intelligence.

ORCID ID: http://orcid.org/0000-0002-6113-7794

Aistė MILIŪTÉ is a teacher/researcher at Vilnius University Business School and entrepreneur within the mineral water and healthcare industries, a founder of AKVAVITA company.

ORCID ID: http://orcid.org/0000-0002-9667-3730

Copyright (C) 2020 by author(s) and VsI Entrepreneurship and Sustainability Center

This work is licensed under the Creative Commons Attribution International License (CC BY).

http://creativecommons.org/licenses/by/4.0/

(c) (i) Open Access 